able to observe them until almost 4:00 p.m. They were not seen after this time.

The birds appeared to be adult males in eclipse plumage. Although they had the characteristic white head spots of the female, the brilliance of the spots was quite different. The small posterior head spot was the brightest; the large spot below the bill was fainter, and the upper bill spot was at times very difficult to see. The birds had a purple wash across the breast and a red-brown coloration on the dark sides. Although they slept most of the day, they did come alive about 2:00 p.m. and were heard to give a series of "Wheet"-like call notes.

There is only one previous record for Harlequin Ducks in Saskatchewan. A mounted male in the Swift Current Collegiate Museum is mentioned in the Blue Jay, 16:65, where it is re- corded that "several pairs of Harlequin Ducks were reported at the Saskatchewan Landing Ferry. A beautiful male specimen was taken on May 31 (1934) ..."

Although I have sean Harlequins before, on the coast of British Columbia, they too were in fall plumage. The British Columbia observation helped me in identifying the birds in this instance, but I wish, on aesthetic grounds, that these birds had still been in possession of their spectacular breeding plumage!

EDITOR'S NOTE: After receiving the above note from Mr. Brunton, we were informed of a second and later sighting of a Harlequin Duck in Regina. This later observation was made by Fred Lahrman, Bill Eddie and Lorne Scott of the Saskatchewan Museum of Natural History at the Condie Park on Highway \#11 just northwest of the city of Regina on October 10,1968 . Lahrman was close enough to photograph the bird and to note the one distinct white spot behind the eye and the lighter shading at the base of the bill. The bird was again sighted on October 22 , and it was shown to me on October 23 by Lorne Scott.-Margaret Belcher.

\title{
ADDITIONAL BIRD SPECIES FOR CREE LAKE
}

by D. Wayne Davis, The School of the Ozarks, Point Lookout, Missouri; and W. Harvey Beck, Manitoba Museum of Man and Nature, Winnipeg

The Sharp-tailed Grouse (Pedioecetes phasianellus) was earlier reported as a hypothetical occasional visitor to Cree Lake (Davis, 1966). During a visit to Cree Lake in June, 1966, we asked trapper Martin Engeman to collect a specimen. Martin saw none during the fall or winter of 1966 but saw and collected a single specimen in late November of 1967. The rather dark-colored specimen was mounted by Miss Doris Montgrant and was donated to the Saskatchewan Museum of Natural History. It was identified as belonging to the subspecies caurus by W. Earl Godfrey of the National Museum, Ottawa, who commented that it would be interesting to know how far east caurus is found as a breeding bird. The Sharptailed Grouse is listed as an uncommon permanent resident of the Lake Athabasca region (Nero, 1963).

On June 25, 1966, we observed a
Common Snipe (Capella gallinago) winnowing on the west side of Lazy Edward Bay. An Eastern Kingbird (Tyrannus tyrannus) was seen nearby. Tree Swallows (Iridoprocne bicolor) were seen on both the west and east sides of Lazy Edward Bay. Martin Brustad, who trapped and fished at Cree Lake for many years, said that bluebirds (Mountain Bluebirds?) nested in boxes he had built at his cabin at Stony Narrows. The above species were not reported by Lahrman (1953) or Davis (1966) for Cree Lake although both species occur farther north in the Lake Athabasca region (Nero, 1963).

\section{LITERATURE CITED}

Davis, D. W. 1966. Some observations of birds at Cree Lake, Saskatchewan. Blue Jay, 24 : 80-85.

Lahrman, F. W. 1964. The bird life at Cree Lake, summer 1963. Blue Jay, $22: 7-8$.

Nero, R. W. 1963. Birds of the Lake Athabasca region, Saskatchewan. Spec. Pub. No. 5, Sask. Nat. Hist. Soc., Regina, 143 pp. \& 12 plates. 